JMKSP (Jurnal Manajemen, Kepemimpinan, dan Supervisi Pendidikan)

Volume 7 Issue 1 (2022) Page 379-388

ISSN 2614-8021 (Online) 2548-7094 (Print)

\title{
Comparison of PGRI Course Study Results Using Google Meet vs. Zoom Meetings
}

\author{
Surmana ${ }^{1}$, Syukri Hamzah ${ }^{2}$ \\ Universitas PGRI Palembang, Universitas Bengkulu \\ Corresponding Author E-mail: surmana785@gmail.com
}

Received 12 December 2021; Revised 31 January 2022; Accepted 20 March 2022

\begin{abstract}
This study was to compare the outcomes of student's instruction in the PGRI course Semester 1 PGSD Study Program, Universitas PGRI Palembang, using Google Meet and Zoom meetings. The research method is quantitative, and the formula for the independent $\mathrm{t}$-test is used (unpaired t-test). In this study, 81 students were sampled, with 40 using Google Meet in 1.Q and 41 using Zoom Meeting in 1.R. data collection instruments included documentation, observation, and tests. The findings revealed a significant difference in learning outcomes between the Google Meet application and Zoom Meeting in the PGRI course at the Universitas PGRI Palembang's PGSD study program. According to the findings of this study, using Google Meet is superior to using Zoom Meeting.
\end{abstract}

Keywords: PGRI Course, Google Meet, Zoom Meeting

\section{Introduction}

Learning has evolved significantly, and the evolution of learning has been felt by educators and students alike. Educators must understand more and understand how to use learning applications, and educators must also be more creative in carrying out the learning process so that students do not become bored while using applications. Educators will encounter a variety of problems when implementing distance learning, including students who are late for attendance, submitting assignments, students who do not ask questions about material they do not understand, students who pay less attention to material, students who are 
unable to draw conclusions on the material provided by educators, and a variety of other issues.

According to Lestari and Yusmiono, (2018), various elements impact the performance of educational programs in the teaching and learning process, including students, curriculum, education personnel, funding, infrastructure and facilities, and other environmental factors. If these requirements are met appropriately and of high quality, the quality of education in Indonesia will improve.

Several factors must be addressed in order to achieve successful educational goals, including instructors, students, leaders, parents, and the learning process. The first is that the learning process utilizing Google Meet with Zoom sessions must be balanced with the topic being taught and can motivate students to be involved in education in order to acquire satisfying educational results.

Teachers as educators have an obligation to improve student learning outcomes, according to Lismawati et al, (2019), so teachers as educators are expected to be creative in managing classes, approaching students, delivering material, and applying methods, models, or learning media in accordance with the material being taught. So that students are motivated in learning activities, their potential may develop, and they can be stimulated to be more passionate in studying and more active, resulting in improved learning results.

Google Meet is a video-based learning tool developed by Google to make the online learning process easier for educators and students. According to Darmuki (2020), the output of Google processing is a video communication service named Google Meet. Zoom Meeting is a video communication program that allows you to communicate with a large group of people without having to meet in person. Zoom Meeting may also be used for online learning between educators and students. Meanwhile, according to Pratiwi et al (2019), zoom cloud meetings is an application that may aid with communication needs on a vast range without having to face to face (Waluyo, 2020).

Google meets and Zoom meetings may be held in a variety of other courses, including the PGRI course. PGRI is a program offered by the University of PGRI Palembang. However, the greatest Google Meet and Zoom sessions that are used each have their own set of flaws and strengths that impact the outcomes of student learning. According to observations made during the Covid-19 era at Universitas PGRI Palembang. Some professors have employed online learning formats such as Google Meet and Zoom sessions at this time. 
The Google Meet learning model is in the form of a video that links many people without the need for them to meet in person to carry out the learning process and can also be utilized via smartphones and computers, whereas the Zoom meeting learning model is similar to Google Meet. Zoom meetings use video to link participants and may be accessed through a laptop or mobile phone.

While Google Meet does not consume a lot of data packets, the capacity for participants to load is less each time it is used and can still be done in rural areas, Zoom Meeting consumes a lot of data packets, the capacity for participants to load more participants each time it is used and requires a strong network. The learning model is used to determine the outcomes of student instruction during the learning process. Based on the background description, the problem of this research can be stated as if there is a comparison of the results of student learning utilizing google meet with zoom meetings in the PGRI Semester 1 PGSD Study Program, Universitas PGRI Palembang.

The research intends to compare the results of student learning utilizing Google Meet with Zoom sessions in the PGRI Semester 1 PGSD Study Program, Universitas PGRI Palembang based on the formulation of the problem above.

According to Jihad and Haris, (2019), learning is a process activity and a basic component of educational level execution, which means that the fulfillment of educational goals is dependent on the success of the student learning process and the environment. Susanto (2018) defines learning as a process of modifying and growing cognitive structures as a result of the contextual adjustment process. Furthermore, learning is an individual action when obtaining education, essentially the internal part of the labor process, according to Karwono (2017). Based on the above reasons, it is possible to infer that learning is a process of change inside a person in order to accomplish the success of the student learning process.

According to Apriyanto and Lestari, (2020), teaching is a necessary. Educating is a person's solid action to obtain excellent, as a bridge for pupils to gain things that are useful for their future. According to Kunandar (2015), the outcomes of education are some of the abilities acquired by students after completing their educational experience. Based on the above considerations, it is possible to conclude that learning outcomes are the competences and abilities of students that have been attained or mastered after the learning process, which are stated numerically. 
Video conferencing, according to Munir (2017), is the usage of a networked computer that allows the user to interact with both visuals and voice. Then, according to Fauzi and Lestari (2020), Google Meet is one of Google's video conferencing software that may be utilized for online learning. Meanwhile, Juniartini (2020) Google Meet is a video conferencing tool invented and developed by Google that is used for online meetings.

Based on some of the definitions of Google Meet provided above, it is possible to deduce that Google Meet is one of the free online tools created by Google in the form of a video that attempts to assist instructors and students in the online learning process.

The meaning of zoom meeting Zoom meeting, according to Paksi (2020), is an application that offers call meetings, both with video/audio solely online. According to Munir (2017), a video conference is an interactive telecommunication technology equipment that allows two or more people to connect by providing two-way voice and video at the same time, even if they are in separate locations. Furthermore, Pratiwi (2019) state that Zoom cloud meeting is an application that can fulfill communication demands with a large number of individuals without having direct touch.

Based on the above definition of zoom meetings, it is possible to deduce that a zoom meeting is an application that may fulfill communication needs with two or more people without direct contact, either by video/audio exclusively. According to Paksi (2020), the benefits of Zoom Meetings are that the video quality in the Zoom Meeting application is clearer because it produces HD quality; it's easy to invite friends, when using this application, users can easily invite friends in several ways, including WhatsApp, Gmail, direct messages, and links; all platforms can use it, whether Android, IOS, Windows, record screens, when running meetings in the Zoom Meeting application; the user can record Zoom Meeting also exchange photographs, files, Google Drive, and a variety of other formats. The free edition of Zoom Meeting has a capacity of 100 people and a length of 40 minutes.

According to Paksi (2020), there is a scarcity of zoom meetings, which can hold 1,000 people for premium zoom meetings but only 100 for free zoom meetings. Zoom meetings may also only utilize one meeting at a time and cannot use multiple meetings at the same time. Furthermore, the amount of time allotted for meetings is limited to a maximum of 40 minutes. If the user has a premium 
account, they may have Zoom meetings with up to 300 participants and without a time restriction.

\section{Methods}

This study employed a quantitative research technique with an independent ttest methodology (unpaired t-test). The sample size in this study was 81 students, with 40 students utilizing Google Meet in 1.Q class and 41 students using Zoom Meeting in 1.R class. The data collecting tool was utilized to document/cover the study process as legitimate proof that this research was carried out. Observation is used to monitor student activity while utilizing Google Meet with Zoom Meeting to carry out the learning process. In addition, the test is utilized to collect data on student learning outcomes in the PGRI course. The test consists of 25 multiplechoice questions with 5 alternative solutions, and it is administered once the material specified has been finished with the same questions.

\section{Results and Discussion}

This study was carried out at the Universitas PGRI Palembang as part of the Elementary School Teacher Education Study Program. This study was run from September 18 through September 23, 2021. This study's meetings are made up of three meetings. Following the specifics of the first two sessions for learning activities, the third meeting distributes the link to the Google form test questions in class groups for the final exam. Student learning outcomes from Google Meet averaged 78 in the Good category, but student learning outcomes from Zoom Meetings averaged 73 in the Good category.

\section{Analysis of Google Meet Class Observation Results and Zoom Meeting Class}

The Observation Sheet is used to track student activities while they are learning online. The data were collected using several steps, the first of which was to mark $(\sqrt{ })$ on each descriptor on the observation sheet, the second of which was to assign a score, the third of which was to convert the score obtained into an activity value, and the fourth of which was to convert the value of student activity into the categories of very active, active, moderately active, less active, and very less active.

We made observations that were carried out during the learning process based on observation data from Semester 1.Q, which amounted to 40 students who got online learning utilizing Google Meet. The active level of class observations using 
Google Meet is 78.41 percent. Meanwhile, utilizing observation data from Semester 1.R, which included 41 students who got online learning through a Zoom conference, the researchers made observations that were carried out during the learning process. The active level of class observations utilizing Zoom Meetings is 76.21 percent.

\section{Data Analysis of Google Meet Class Learning Results}

The table below shows data analysis of student learning results in the PGRI Semester 1.Q PGSD Study Program at Universitas PGRI Palembang taught utilizing Google Meet:

\section{Table 1. Distribution of Google Meet Class Student Learning Results}

\begin{tabular}{ccccc}
\hline No & Interval & F & Percentage $(\%)$ & Notification \\
\hline 1 & $86-100$ & 2 & $5 \%$ & Very Good \\
2 & $71-85$ & 28 & $70 \%$ & Good \\
3 & $56-70$ & 10 & $25 \%$ & Enough \\
4 & $41-55$ & - & - & Poor \\
5 & $0-40$ & - & - & Very Poor \\
$\Sigma$ & & 40 & $100 \%$ & \\
\hline \multicolumn{2}{c}{ Average } & 78 & Good \\
\hline
\end{tabular}

According to the chart above, the majority of the outcomes of student learning using Google Meet are in the Good category, because the average result of 78 has a value range of 71-85.

\section{Data Analysis of Zoom Meeting Class Learning Results}

The table below shows data analysis of student learning results in the PGRI Semester 1.R PGSD Study Program at Universitas PGRI Palembang taught through zoom meetings: 


\section{Table 2. Distribution of Zoom Meeting Class Student Learning Results}

\begin{tabular}{ccccc}
\hline No & Interval & $\mathrm{F}$ & Percentage (\%) & Notification \\
\hline 1 & $86-100$ & 1 & $3,03 \%$ & Very Good \\
2 & $71-85$ & 19 & $30,30 \%$ & Good \\
3 & $56-70$ & 19 & $63,64 \%$ & Enough \\
4 & $41-55$ & 2 & $3,03 \%$ & Poor \\
5 & $0-40$ & - & - & Very Poor \\
$\Sigma$ & & 41 & $100 \%$ & \\
\hline \multicolumn{2}{c}{ Average } & & 73 & Good \\
\hline
\end{tabular}

Based on the table above, it is possible to assume that the majority of the outcomes of student learning utilizing zoom meetings are in the Good category, because the average results of 73 are within a range of 71-85.

It is derived from the calculation of the results of student learning utilizing Google Meet with Zoom Meeting $\mathrm{F}_{\text {calculate }} ; \mathrm{F}=\frac{\text { Biggest Variance }}{\text { Smallest Variance }}=\frac{58.71}{40.01}=1.47$

On the basis of the above calculations, it is known that $\mathrm{F}_{\text {calculate }}=1.47$ and for $F_{\text {table }}$ with dk as numerator $=\mathrm{n}-1$ (biggest variance) and also the denominator (smallest variance) with significant level $\alpha=0,05$. Therefore $F_{\text {calculate }}<F_{\text {table }} /$ $1.47<1.79$ it can be seen that the data is homogeneous.

Next, test the hypothesis by calculating in $\mathrm{t}_{\text {table }}$ with $\mathrm{dk}=\left(n_{1}+n_{2}-2\right)=$ $(40+41-2)=79$ dengan taraf signifikan $\alpha 0.05$. Maka $t_{\text {calculate }}=16.580$ serta $\mathrm{t}_{\text {table }}=1.664$ shows that $\mathrm{t}_{\text {calculate }}>\mathrm{t}_{\text {table }} / 16.580>1,664$. It can be concluded that $\mathrm{H}_{\mathrm{o}}$ rejected and $\mathrm{H}_{\mathrm{a}}$ accepted. In the PGRI course, a comparison of student learning results utilizing Google Meet versus Zoom Meeting was made.

In this study, researchers confront challenges when doing research, such as students who do not always fully participate in Google Meet and Zoom sessions due to a lack of data and trouble signaling. This, however, is not a big barrier for pupils to remain passionate, active, and engaged in the learning process until it is completed. Students are also passionate and engaged in completing the duties assigned by the teacher. Students in Google Meet classes are more engaged and diligent in pursuing the learning process until it is completed, and they are also meticulous in working on and collecting homework assigned by the instructor (Sawitri, 2020).

According to Fiyanti, (2020), the results of previous relevant studies with the title "Differences in Student Mathematics Learning Outcomes between E- 
Learning Learning Assisted by Zoom Applications and Google Classroom" indicate that there are differences in student mathematics learning outcomes between e-learning learning with the help of the zoom application and google classroom. Furthermore, according to Fauzi and Lestari (2020), the results of a previous relevant study titled "Implementation of Individual Head Number Learning Based on Google Meet and Classroom on Trigonometry material" show that most students are satisfied with the teaching and learning process of Individual Head Number-based Google Meet and Classroom, with 66.7 percent happy and 33.3 percent quite satisfied.

While the results of previous relevant research, according to Darmuki, (2020), with the title "Efforts to Improve Students' Speaking Skills Using the Media Google Meet Application Based on Uploading Video Assignments on Youtube During the Covid-19 Pandemic," showed that using the upload-based google meet application media assignments on youtube can improve student speaking skills learning outcomes in class IB of the PBSI IKIP PGRI Bojonegoro Study Program for the 2020/2021 Academic Year.

\section{Conclusion}

The findings reveal that when comparing learning outcomes, Google Meet outperforms Zoom Meeting, with the average score of students using Google Meet being higher than the average score of students using Zoom Meeting. However, there are pros and downsides to carrying out this research. The findings of this study support the previously presented hypothesis, which is a comparison of student learning outcomes in the PGRI course in the PGSD study program at PGRI University Palembang utilizing Google Meet vs Zoom Meetings.

\section{Acknowledgment}

We thank to Rector Universitas PGRI Palembang, Universitas Bengkulu and colleagues who have supported this study.

\section{References}

Apriyanto, A., \& Lestari, N. D. (2020). Analisis Prestasi Belajar Siswa Pada Mata Pelajaran Ekonomi di SMA PGRI 4 Palembang [Analysis of Student Achievement in Economics at SMA PGRI 4 Palembang]. Jurnal Neraca: Jurnal Pendidikan dan Ilmu Ekonomi Akuntansi, 4(1), 97-107. 
Darmuki, A. (2020). Upaya Meningkatkan Kemampuan Berbicara Mahasiswa Menggunakan Media Aplikasi Google Meet Berbasis Unggah Tugas Video di Youtube Pada Masa Pandemi Covid-19 [Efforts to Improve Students' Speaking Ability Using Google Meet Application Media Based on Uploading Video Assignments on Youtube During the Covid-19 Pandemic].

Fauzi, F. A. \& Lestari, P. (2020). Implementasi Pembelajaran Individual Head Number Berbasis Google Meet dan Classroom Pada Materi Trigonometri [Implementation of Individual Head Number Learning Based on Google Meet and Classroom on Trigonometry Materials]. Jurnal Ilmiah Matematika dan Pendidikan Matematika, 10(02).

Fiyanti, O. (2020). Perbedaan Hasil Belajar Matematika Mahasiswa antara Pembelajaran E-Learning Berbantuan Aplikasi Zoom dan Google Classroom [Differences in Student Mathematics Learning Outcomes between E-Learning Learning Assisted by Zoom Applications and Google Classroom]. PMAT 019.

Jihad, A., \& Haris, A. (2019). Evaluasi Pembelajaran [Learning Evaluation]. Yogyakarta: Multi Pressindo.

Juniartini, N.M.E., \& Rasna, I. W. (2020). Pemanfaatan Aplikasi Google Meet dalam Keterampilan Menyimak dan Berbicara Untuk Pembelajaran Bahasa Pada Masa Pandemi Covid-19 [Utilization of the Google Meet Application in Listening and Speaking Skills for Language Learning During the Covid19 Pandemic]. Jurnal Pendidikan dan Pembelajaran Bahasa Indonesia, 09(02).

Kunandar. (2015). Penilaian Autentik (Penilaian Hasil Belajar Mahasiswa Berdasarkan Kurikulum 2013) [Authentic Assessment (Assessment of Student Learning Outcomes Based on the 2013 Curriculum)]. Jakarta: Raja Grafindo Persada.

Karwono. \& Mularsih, H. (2017). Belajar dan Pemanfaatan Sumber Belajar [Learning and Utilization of Learning Resources]. Depok: Raja Grafindo Persada. 
Lestari, N. D., \& Yusmiono, B. A. (2018). Analisis Penggunaan Sarana dan Prasarana untuk Menunjang Kegiatan Belajar Mahasiswa di Universitas PGRI Palembang Tahun Akademik 2016/2017 [Analysis of the Use of Facilities and Infrastructure to Support Student Learning Activities at PGRI University Palembang in the 2016/2017 Academic Year]. JMKSP (Jurnal Manajemen, Kepemimpinan, dan Supervisi Pendidikan), 3(1), 41-51.

Lismawati, L., Ahmad, S., \& Lestari, N. D. (2019). Hubungan Antara Pendekatan Pembelajaran Peer Group Dengan Hasil Belajar Siswa Pada Mata Pelajaran Ekonomi SMA Negeri 1 Palembang [The Relationship Between Peer Group Learning Approach and Student Learning Outcomes in Economics Subject at SMA Negeri 1 Palembang]. PROMOSI: Jurnal Program Studi Pendidikan Ekonomi, 7(2).

Munir. (2017). Pembelajaran Digital [Digital Learning]. Bandung: Alfabeta.

Paksi, H. P. \& Ariyanti, L. (2020). Sekolah dalam Jaringan [Online School]. Surabaya: Scorpindo Media Pustaka.

Pratiwi, A. D. (2019). Potensi Aplikasi Zoom Cloud Meetings Dalam Pembelajaran di Era Digital [The Potential of Zoom Cloud Meetings Applications in Learning in the Digital Age]. Prosiding Seminar Nasional FKIP 2019, ISBN : 978-623-92630-0-3.

Sawitri, D. (2020). Penggunaan Google Meet Untuk Work From Home di Era Pandemi Coronavirus disease 2019 (Covid-19) [Use of Google Meet to Work From Home in the Era of the 2019 Coronavirus disease (Covid-19) Pandemic]. Jurnal Prioritas: Jurnal Pengabdian Masyarakat, 02(1)

Susanto, P. (2018). Belajar Tuntas Filosofi, Konsep, dan Implementasi [Complete Learning Philosophy, Concepts, and Implementation]. Jakarta: PT Bumi Aksara.

Waluyo, ST. (2020). Blended Learning untuk Pelatihan Vokasi [Blended Learning for Vocational Training]. Bandung: Srikandi Empat Widya Utama. 